\title{
Prevalence of Mental Disorders in Martinique, French West Indies: A Community-based Epidemiological Study
}

\author{
J Lacoste ${ }^{1,3}$, S Merle ${ }^{2}$, N Ballon ${ }^{1,4}$, A Charles-Nicolas ${ }^{1}$, G Ursulet $^{1}$, A Messiah ${ }^{3}$
}

\begin{abstract}
Objective: This study aimed to estimate the prevalence of mental disorders in the population of Martinique, as part of the survey entitled 'Mental Health in the General Population - Images and Realities' (Santé Mentale en Population Générale - Images et Réalités). The survey was a multicentre epidemiological study in the general population, conducted in mainland France and French overseas islands between 1997 and 2006, under the authority of the World Health Organization Collaborating Centre for Training and Research in Mental Health (Lille, France). Methods: The study took place in 2000. Participants aged 18 years or over were recruited in public places, using the quota sampling method, and interviewed using the Mini International Neuropsychiatric Interview.

Results: A total of 900 participants (52.7\% women) with a mean age of 43 years completed the survey. Lifetime prevalence of any mental disorder was 29\%. Mood (15\%) and anxiety disorders (17\%) were the most frequent. The rate of suicide attempts was low (4.2\% lifetime), while the frequency of suicidal thoughts was high (11\% past month) and similar to the frequency in mainland France.

Conclusion: Mental disorders, especially mood and anxiety disorders, were as frequent in Martinique as in mainland France. The lower rates of suicide attempts, in spite of high rates of suicidal thoughts, might deserve further investigation. Our results should strengthen the development of a system of diagnosis and care for these disorders, especially to prevent suicidal behaviours and reduce morbidity and mortality.
\end{abstract}

Keywords: Epidemiology, health survey, Martinique, mental disorders, prevalence

\section{Prevalencia de los trastornos mentales en Martinica, Antillas Francesas: un estudio epidemiológico comunitario}

\author{
J Lacoste ${ }^{1,3}$, S Merle ${ }^{2}$, N Ballon ${ }^{1,4}$, A Charles-Nicolas ${ }^{1}$, G Ursulet ${ }^{1}$, A Messiah $^{3}$
}

\begin{abstract}
RESUMEN
Objetivo: Este estudio tuvo por objeto estimar la prevalencia de los trastornos mentales en la población de Martinica, como parte de la encuesta intitulada 'Salud Mental en la Población General-Imágenes y Realidades'(Santé mentale at Population Générale - Images et Réalités).
\end{abstract}

From: ${ }^{1} \mathrm{CHU}$ de Martinique, Department of Psychiatry and Addictology, CHU Martinique University Hospital, Fort-de-France, Martinique, French West Indies, ${ }^{2}$ Regional Health Observatory, Fortde-France, Martinique, French West Indies, ${ }^{3}$ CESP/Inserm U1018Team IPSOM, Paris, France and ${ }^{4}$ UMR 1253, iBrain, Université de Tours, Inserm \& CHRU Tours, France.
Correspondence: Dr J Lacoste, Service de Psychiatrie et Addictologie, Hôpital Pierre Zobda Quitman, CHU de Martinique, CS 90632, F-97261 Fort de France cedex, Martinique, French West Indies. Email: jerome.lacoste@chu-martinique.fr 
La encuesta fue un estudio epidemiológico multicéntrico en la población general, realizado en Francia continental y en las islas francesas de ultramar entre 1997 y 2006, bajo la autoridad del Centro de Colaboración de la Organización Mundial de la Salud para la Formación y la Investigación de la Salud Mental (Lille, Francia).

Métodos: El estudio tuvo lugar en el año 2000. Los participantes mayores de 18 años fueron reclutados en lugares públicos, utilizando el método de muestreo por cuotas, y entrevistados usando la Mini Entrevista Neuropsiquiátrica Internacional.

Resultados: Un total de 900 participantes (52.7\% mujeres) con edad promedio de 43 años completó la encuesta. La prevalencia de por vida de cualquier trastorno mental fue de $29 \%$. Los estados de ánimo (15\%) y los trastornos de ansiedad (17\%) fueron los más frecuentes. La tasa de intentos de suicidio fue baja (4.2\% por tiempo de vida), mientras que la frecuencia de los pensamientos suicidas fue alta (11\% el mes pasado) y similar a la frecuencia en la Francia continental.

Conclusión: Los trastornos mentales, especialmente los estados de ánimo y los trastornos de ansiedad, eran tan frecuentes en Martinica como en la Francia continental. Las tasas más bajas de intentos de suicidio, a pesar de los altos índices de pensamientos suicidas, podrían merecer investigación adicional. Nuestros resultados deben fortalecer el desarrollo de un sistema de diagnóstico y cuidado para estos trastornos, especialmente para prevenir comportamientos suicidas y reducir la morbilidad y la mortalidad.

Palabras clave: Epidemiología, encuesta de salud, Martinica, trastornos mentales, prevalencia

West Indian Med J 2018; 67 (4): 318

\section{INTRODUCTION}

Mental disorders are a public health problem worldwide. Both at the national and local levels, the development of care and prevention programmes adapted to the needs of the population have to lean on epidemiological data. Prevalence of mental disorders in the general population has been assessed in several countries (1), notably in the United States of America (2-4), Europe (5-7) and Australia (8). However, in the Caribbean, there is a paucity of recent literature on the prevalence of mental disorders (9), with a major focus on psychotic disorders in Afro-Caribbean immigrants in European countries (10).

In France, the survey 'Mental Health in the General Population - Images and Realities' (Santé Mentale en Population Générale - Images et Réalités; SMPG) was conducted between 1997 and2006, by the NorthernFrench Psychiatric Epidemiology Association (Association Septentrionale d'Epidemiologie Psychiatrique) and the World Health Organization Collaborating Centre for Training and Research in Mental Health, Lille, France (WHO-CC), in collaboration with the French Ministry of Health (11). Participants were recruited in 71 centres in mainland and overseas France. For each centre, around 900 subjects were recruited in public places, using the quota sampling method. Martinique was one of the centres; its survey was carried out in 2000.

With an area of $1100 \mathrm{~km}^{2}$, Martinique is a French overseas island with a population of 385500 in 2013 (12), the majority of whom being Afro-Caribbean (fluent in both French and Creole). Since 1950, Martinique has experienced a major transition socially and economically, with a rapidly growing economy, a significant increase in per capita gross domestic product, and dramatic social and psychological changes, evolving within two generations from a rural to the current industrialized society (13). Based on the same healthcare system as other regions in mainland France, the actors of the Martinique's mental health system have nevertheless to deal with the consequences of the rapid evolution in Martinique's society (13).

As part of the SMPG survey, the aim of this study was to measure the prevalence of the most frequent mental disorders in a sample representative of the general population of Martinique, in order to design mental healthcare programmes adapted to the local reality.

\section{SUBJECTS AND METHODS}

The method of the SMPG survey has been described in detail elsewhere (14). The study protocol and 
questionnaires were reviewed and approved by a national ethics committee.

Non-institutionalized and non-homeless subjects aged 18 years or over were recruited in public places in 2000. Subjects were selected by quota sampling stratified by age, gender, educational and occupational levels, socio-economic status and place of residence; the Martinique population structure was given by the 1999 national census (15).

After written consent was obtained, a 50-item structured questionnaire was administered face-to-face. Interviewers (nurses, nursing students and social workers) received a special three-day training course by WHO-CC experts. An expert team created a FrenchCreole translation using the double translation approach. However, Creole was rarely used $(0.2 \%)$ because most participants spoke French. Each interviewer was supervised to ensure that questions were asked correctly and data were properly collected.

Sociodemographic data included gender, age, marital status, educational level, employment, monthly family income, household size, and religion.

The World Health Organization's ICD-10 diagnosis of mental disorders was assessed using the Mini International Neuropsychiatric Interview (MINI) (16).

Disorders included:

- mood disorders: major depressive disorder (MDD) - single (F32), MDD - recurrent (F33), dysthymia (F34), current mania (F30) and lifetime mania (F31);

- anxiety disorders: time frame:

o one month: panic disorder (F41.0), agoraphobia (F40.0), social anxiety (F40.1), obsessive compulsive disorder (F42), post-traumatic stress disorder (F43.1); and o six months: generalized anxiety disorder (F41.1);

- $\quad$ psychotic syndrome (lifetime);

- current bulimia and anorexia (three months); and

- $\quad$ substance-use disorders (12 months).

Suicidal behaviours were assessed using the MINI criteria, which explore thoughts or wishes related to death and suicidal ideations, and suicide attempts. This assessment yielded three risk categories: low, medium and high.

\section{Statistical analyses}

Statistical analyses were done with Epi-Info, version 6 (CDC Atlanta, 1994). We first performed univariate analysis of sociodemographic characteristics. Then, psychiatric diagnoses were analysed by sociodemographic variables, using analysis of variance and t-test for quantitative data, and Chi-square and Fisher's exact test for categorical data. Significance level was set at 0.05.

\section{RESULTS}

A total of 900 participants (426 men and 474 women) completed the survey, $92 \%$ of whom were from Martinique, $1 \%$ from Guadeloupe, 5\% from mainland France and 2\% from various foreign countries (mainly Dominica, Saint Lucia and Haiti). The mean age was 43 years ( standard deviation $=17$ years; range $=18-91$ years $)$.

As for education, $22 \%$ had a primary school level (one to five years) and 23\% a university level (more than 12 years).

Sixty-six per cent of households consisted of fewer than four persons, and 49\% earned less than $1300 €$ per month. Of those, $8 \%$ had less than $533 €$ per month (Table 1).

At least one mental disorder was diagnosed in $29 \%$ of the participants.

Participants with at least one mental disorder, compared with those without any mental disorder, were more likely to be women, unemployed and single/widowed/ divorced. The two most frequent disorders were mood disorders and anxiety disorders, affecting 15\% and 17\% of the participants, respectively (Table 2).

Prevalence of suicidal risk (defined as having had suicidal thoughts in the month before the assessment) was $11 \%$ and was more in women than men. Of these, $62 \%$ were at low suicidal risk ('wish to be dead' or 'desire to hurt oneself in the past month' or 'lifetime suicide attempt'), $15 \%$ at medium suicidal risk ('suicide ideas in the past month' or 'desire to hurt oneself in the past month' and 'lifetime suicide attempt'), and 23\% at high suicidal risk ('having established a way to commit suicide' or 'suicide attempt in the past month' or 'suicide ideas in the past month' and 'lifetime suicide attempt'). Compared with low suicidal risk, higher suicidal risk (both medium and high categories) was strongly associated with MDD - single episode (odds ratio (OR): 9.5; $95 \%$ confidence interval $(\mathrm{CI}): 4.0,22.6)$ and dysthymia (OR: 3.5; 95\% CI: 0.6, 20.2), but not with MDD - recurrent (OR: $0.53 ; 95 \% \mathrm{CI}: 0.17,1.6)$ or any anxiety disorder (OR: 0.23 ; 95\% CI: 0.36, 1.5).

Alcohol-use disorder affected 3\% of the study population (2\% abuse and 1\% dependence) and were more frequent among men than women. Cannabis users were 
$4.5 \%$. Substances-use disorder affected $1.7 \%$ of the study population $(0.9 \%$ abuse and $0.8 \%$ dependence) and were more frequent among male, young, single and unemployed participants.

No diagnosis of current anorexia was made; current bulimia nervosa affected $1 \%$ of the participants, but only women aged between 18 and 49 years.

\section{DISCUSSION}

This study was the first exploring the prevalence of mental disorders conducted in a community sample in Martinique. As a part of the SMPG surveys, three other

Table 1: Characteristics of the study population

\begin{tabular}{|c|c|c|}
\hline & $\mathbf{n}$ & $\%$ \\
\hline \multicolumn{3}{|l|}{ Gender $(\mathrm{n}=900)$} \\
\hline Male & 426 & 47.3 \\
\hline Female & 474 & 52.7 \\
\hline \multicolumn{3}{|l|}{ Age (years) $(n=900)$} \\
\hline $18-29$ & 239 & 26.6 \\
\hline $30-39$ & 208 & 23.1 \\
\hline $40-49$ & 163 & 18.1 \\
\hline $50-59$ & 118 & 13.1 \\
\hline $60-74$ & 172 & 19.1 \\
\hline \multicolumn{3}{|l|}{ Marital status $(\mathrm{n}=899)$} \\
\hline Single & 360 & 40.0 \\
\hline Married & 431 & 47.9 \\
\hline Divorced/separated & 58 & 6.5 \\
\hline Widowed & 50 & 5.6 \\
\hline \multicolumn{3}{|l|}{ Educational level $(\mathrm{n}=882)$} \\
\hline Illiterate & 13 & 1.5 \\
\hline Primary school & 181 & 20.5 \\
\hline Secondary school & 278 & 31.5 \\
\hline Baccalaureate or university level & 410 & 46.5 \\
\hline \multicolumn{3}{|l|}{ Employment $(\mathrm{n}=900)$} \\
\hline Employed & 503 & 55.9 \\
\hline Retired & 147 & 16.3 \\
\hline Unemployed & 97 & 10.8 \\
\hline Students & 85 & 9.4 \\
\hline Others & 68 & 7.6 \\
\hline \multicolumn{3}{|l|}{ Monthly family income $(€)(\mathrm{n}=845)$} \\
\hline Less than 534 & 67 & 7.9 \\
\hline $534-838$ & 139 & 16.5 \\
\hline $839-1295$ & 212 & 25.1 \\
\hline $1296-2515$ & 270 & 31.9 \\
\hline $2515-6402$ & 144 & 17.0 \\
\hline 6403 or more & 13 & 1.6 \\
\hline \multicolumn{3}{|l|}{ Persons in family $(\mathrm{n}=889)$} \\
\hline Single & 141 & 15.9 \\
\hline Couple & 202 & 22.7 \\
\hline $3-4$ & 389 & 43.7 \\
\hline $5-6$ & 126 & 14.2 \\
\hline $7-8$ & 24 & 2.7 \\
\hline 9 or more & 7 & 0.8 \\
\hline
\end{tabular}

French overseas islands had used the same study protocol: Guadeloupe, Reunion Island and New Caledonia. Results of these surveys have been published elsewhere (17-19).

In our study, at least one mental disorder was diagnosed in $29 \%$ of the study population. Our results were similar with those in mainland France (31\%), Guadeloupe (32\%) and Reunion Island (30\%), but lower than those in New Caledonia (46\%) (17-20). Mood and anxiety disorders were the most common disorders in our study, as well as in the other overseas territories.

Prevalence of psychotic syndrome $(3.3 \%)$ was in line with the rate in mainland France $(2.8 \% ; \mathrm{n}=$ $36000)$ (20). In a previous paper, Ballon et al compared the prevalence of psychosis in Martinique and Guadeloupe combined to partial data from the first seven French sites $(n=5502)$, and found a significant discrepancy between mainland France (1.8\%) and French West Indies (4.4\%) $(p<0.0001)(21)$. Therefore, it can be said that the difference between the two islands and mainland France $(4.4 \%$ versus $2.8 \%)$ remains statistically significant $(p<0.0001)$ even when considering the larger number of French sites (44 sites; $\mathrm{n}=36000$ ) (20).

In our study, $4.2 \%$ of the participants had a lifetime prevalence of at least one suicide attempt, while data from the national survey found a lifetime prevalence of $7.8 \%$ (22). Even though lifetime prevalence of suicide attempts was lower in Martinique than in mainland France, suicidal risk rates were quite similar, with $11 \%$ in Martinique and $13.7 \%$ in mainland France. Our results may be due to an under-reporting of suicide attempts in this population, with non-acceptance or tendency to trivialization and minimization of such behaviour in the West Indian society, particularly for cultural and religious reasons, more so than in mainland France.

\section{Limitations}

Firstly, due to inclusion criteria, several important population segments were not represented, such as those in institutions, in hospitals, the homeless and prison inmates. Thus, the prevalence estimate of mental disorders may have been under-estimated. In addition, as in other SMPG studies, patients with mental illness might be more reluctant than others to participate in the survey.

Although the WHO-CC supported the selection of the MINI (16), such instrument had not been validated in the French West Indies. However, the use of the same instrument in all surveys conducted in France allowed 
Table 2: Prevalence of mental disorders by Mini International Neuropsychiatric Interview, according to sociodemographic characteristics (\% in subpopulation)

\begin{tabular}{|c|c|c|c|c|c|c|c|c|c|c|}
\hline & $\begin{array}{c}\text { At least } \\
\text { one mental } \\
\text { disorder } \\
(\mathrm{n}=\mathbf{2 6 0})\end{array}$ & $\begin{array}{c}\text { At least } \\
\text { one mood } \\
\text { disorder } \\
(n=135)\end{array}$ & $\begin{array}{c}\text { Major } \\
\text { depressive } \\
\text { disorder } \\
\text { - single } \\
(\mathrm{n}=119)\end{array}$ & $\begin{array}{c}\text { Major } \\
\text { depressive } \\
\text { disorder } \\
\text { - recurrent } \\
(\mathrm{n}=\mathbf{5 8})\end{array}$ & $\begin{array}{c}\text { At least } \\
\text { one anxiety } \\
\text { disorder } \\
(\mathrm{n}=\mathbf{1 5 5})\end{array}$ & $\begin{array}{c}\text { Suicidal } \\
\text { risk } \\
(n=99)\end{array}$ & $\begin{array}{l}\text { Suicide } \\
\text { attempt } \\
(n=37)\end{array}$ & $\begin{array}{c}\text { Psychotic } \\
\text { syndrome } \\
(\mathrm{n}=\mathbf{3 0})\end{array}$ & $\begin{array}{c}\text { Alcohol-use } \\
\text { disorder } \\
(\mathrm{n}=27)\end{array}$ & $\begin{array}{c}\text { Substance- } \\
\text { use } \\
\text { disorder } \\
(\mathrm{n}=15)\end{array}$ \\
\hline Total $(\mathrm{n}=900)$ & 29.2 & 15.0 & 13.2 & 6.4 & 17.2 & 11.0 & 4.2 & 3.3 & 3.0 & 1.7 \\
\hline Gender $(p)$ & 0.001 & 0.0006 & 0.0003 & 0.004 & 0.001 & 0.04 & NS & NS & 0.005 & 0.0001 \\
\hline Men $(n=426)$ & 23.9 & 10.8 & 8.9 & 4.0 & 15.5 & 8.2 & 3.3 & 2.3 & 4.7 & 3.5 \\
\hline Women $(n=474)$ & 33.9 & 18.8 & 17.1 & 8.7 & 22.0 & 13.5 & 4.9 & 4.2 & 1.5 & 0.0 \\
\hline Age $(p)$ & NS & NS & NS & NS & NS & 0.002 & NS & NS & NS & 0.004 \\
\hline $18-29$ years & 35.6 & 18.8 & 17.1 & 7.9 & 21.7 & 16.3 & 5.9 & 4.2 & 2.5 & 4.2 \\
\hline 30-39 years & 27.2 & 13.5 & 11.5 & 6.3 & 13.9 & 9.6 & 4.3 & 2.9 & 1.9 & 1.9 \\
\hline $40-49$ years & 27.3 & 13.5 & 12.3 & 6.7 & 15.9 & 15.3 & 5.0 & 3.7 & 3.1 & 0.6 \\
\hline $50-59$ years & 31.3 & 18.6 & 15.2 & 6.8 & 19.5 & 6.8 & 3.4 & 4.2 & 5.9 & 0.0 \\
\hline $60-74$ years & 23.2 & 10.5 & 9.3 & 4.0 & 14.5 & 4.1 & 1.2 & 1.7 & 2.9 & 0.0 \\
\hline Marital status ( $p$ ) & 0.0008 & 0.04 & NS & NS & NS & NS & NS & 0.03 & NS & 0.003 \\
\hline Single & 27.8 & 18.6 & 16.4 & 8.3 & 20.5 & 13.6 & 4.3 & 5.3 & 2.8 & 3.6 \\
\hline Married & 24.1 & 13.0 & 12.1 & 5.1 & 14.8 & 9.0 & 3.3 & 1.6 & 3.5 & 0.5 \\
\hline Separated & 31.6 & 15.5 & 8.6 & 8.6 & 18.9 & 13.8 & 10.3 & 5.2 & 0.0 & 0.0 \\
\hline Widowed & 20.0 & 6.0 & 6.0 & 2.0 & 12.0 & 6.0 & 4.0 & 2.0 & 4.0 & 0.0 \\
\hline Employment $(p)$ & 0.04 & NS & NS & NS & 0.01 & NS & NS & NS & NS & NS \\
\hline Employed $(\mathrm{n}=503)$ & 26.5 & 13.3 & 11.7 & 5.7 & 14.5 & 11.1 & 3.2 & 2.9 & 3.6 & 0.99 \\
\hline Unemployed $(\mathrm{n}=397)$ & 32.6 & 17.1 & 15.1 & 7.3 & 20.6 & 10.8 & 5.4 & 3.7 & 2.3 & 2.5 \\
\hline
\end{tabular}

$\mathrm{NS}=$ non-significant

comparisons between locations and subsequent adaptations of local mental health policies.

Replication studies are required, especially for comparison between French and English Caribbean islands. Specific studies in the Caribbean population living in mainland France may be relevant.

In conclusion, our study found that mental disorders, especially mood and anxiety disorders, were as prevalent in Martinique as in mainland France. These results should strengthen the development of a system of diagnosis and care for these disorders, especially to prevent suicidal behaviours and reduce morbidity and mortality.

\section{ACKNOWLEDGEMENTS}

This survey was carried out in collaboration with Colson Psychiatric Hospital, the University Hospital of Fort-de-France, the Institute for Training in Nursing and the Regional Health Observatory of Martinique. It was funded by Colson Psychiatric Hospital, the Regional Council and the Direction of Health and Social Development.

The authors would like to thank local coordinators (N Ballon, S Merle, G Ursulet), local supervisors (M Assogba, R Brunod, B Cazenave, JP Desbeuf, B DelilleManières, M Dietsch, JD Even, E Guillaudat, N Nelzy, S Nogard, F Oliny, M Paris, V Petit-Jean-Roget), and interviewers (M Assogba, N Assogba, N Ballon, K Bonnialy, J Brissit, S Bucher, S Chatenay, J ConneBizy, F Cyrille, L Dambo, J Denis, E Guillaudat, M Elisabeth, R Eridan, T Gerald, C Hayot, MC Jean, T Lacrampe, A Latouchent, S Louison, R Marie-Anne, MA Marine, S Merle, M Michalon, F Montredon, N Nelzy, F Oliny, M Paris, S Paulin, R Robert, J Rosine, O Terosier, G Ursulet, N Verroux, MN Vitulin).

The SPMG was carried out by the WHO-CC. The scientific coordinator was JL Roelandt. The methodologic coordinator was A Caria. The general coordinators were A Kergall (foreign centres) and G Mondière (French centres).

\section{REFERENCES}

1. Demyttenaere K, Bruffaerts R, Posada-Villa J, Gasquet I, Kovess V, Lepine $\mathrm{J}$ et al. Prevalence, severity, and unmet need for treatment of mental disorders in the World Health Organization World Mental Health Surveys. JAMA 2004; 291: 2581-90.

2. Regier DA, Farmer ME, Rae DS, Locke BZ, Keith SJ, Judd LL et al. Comorbidity of mental disorders with alcohol and other drug abuse: results from the Epidemiologic Catchment Area (ECA) study. JAMA 1990; 264: 2511-8.

3. Kessler RC, McGonagle KA, Zhao S, Nelson CB, Hughes M, Eshleman $\mathrm{S}$ et al. Lifetime and 12-month prevalence of DSM-III-R psychiatric disorders in the United States. Results from the National Comorbidity Survey. Arch Gen Psychiatry 1994; 51: 8-19.

4. Kessler RC, Berglund P, Demler O, Jin R, Merikangas KR, Walters EE. Lifetime prevalence and age-of-onset distributions of DSM-IV disorders 
in the National Comorbidity Survey Replication. Arch Gen Psychiatry 2005; 62: 593-602.

5. Alonso J, Angermeyer MC, Bernert S, Bruffaerts R, Brugha TS, Bryson $\mathrm{H}$ et al. Prevalence of mental disorders in Europe: results from the European Study of the Epidemiology of Mental Disorders (ESEMeD) project. Acta Psychiatr Scand 2004; 109 (suppl 420): 21-7.

6. Bijl RV, Ravelli A, van Zessen G. Prevalence of psychiatric disorder in the general population: results of The Netherlands Mental Health Survey and Incidence Study (NEMESIS). Soc Psychiatry Psychiatr Epidemiol 1998; 33: 587-95.

7. Jenkins R, Lewis G, Bebbington P, Brugha T, Farrell M, Gill B et al. The National Psychiatric Morbidity Surveys of Great Britain - initial findings from the household survey. Int Rev Psychiatry 2003; 15: 29-42.

8. Slade T, Johnston A, Oakley Browne MA, Andrews G, Whiteford H. 2007 National Survey of Mental Health and Wellbeing: methods and key findings. Aust NZJ Psychiatry 2009; 43: 594-605.

9. Sharpe J, Shafe S. Mental health in the Caribbean. In: Roopnarine JL, Chadee D, eds. Caribbean psychology: indigenous contributions to a global discipline. Washington, DC, United States of America: American Psychological Association; 2016: 305-25.

10. Tortelli A, Errazuriz A, Croudace T, Morgan C, Murray RM, Jones PB et al. Schizophrenia and other psychotic disorders in Caribbean-born migrants and their descendants in England: systematic review and meta-analysis of incidence rates, 1950-2013. Soc Psychiatry Psychiatr Epidemiol 2015; 50: 1039-55.

11. World Health Organization Collaborating Centre for Training and Research in Mental Health, Lille, France. Accessed November 22, 2018. Available from: http://www. ccomssantementalelillefrance.org/?q=content $/$ sant $\% \mathrm{C} 3 \% \mathrm{~A} 9$-mentale-en-population-g\% $\% 3 \% \mathrm{~A} 9 \mathrm{n} \% \mathrm{C} 3 \% \mathrm{~A} 9$ rale $\% \mathrm{C} 2 \% \mathrm{~A} 0$-images-etr\%C3\%A9alit\%C3\%A9s-smpg.

12. INSEE. Recensement de la population - 385551 habitants en Martinique

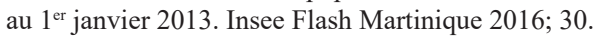

13. Massé R. Détresse créole. Ethnoépidémiologie de la détresse psychologique à la Martinique. Québec, Canada: Presses de l'Université Laval; 2008.

14. Roelandt JL, Caria A, Mondiere G. La santé mentale en population générale: images et réalités. Présentation générale de l'enquête. Info Psychiatr 2000; 76: 279-92.

15. Chauvet A. Recensement de la population 1999 en Martinique: le nouveau visage de la Martinique à l'aube du XXIe siècle. Premiers résultats. INSEE Martinique; 2000.

16. Sheehan DV, Lecrubier Y, Sheehan KH, Amorim P, Janavs J, Weiller E et al. The Mini-International Neuropsychiatric Interview (M.I.N.I.): the development and validation of a structured diagnostic psychiatric interview for DSM-IV and ICD-10. J Clin Psychiatry 1998; 59 (suppl 20): 22-33.

17. Eynaud M, Casse R, Dellas B, Plenet J, Didier P, Girard B et al. La santé mentale en Guadeloupe: résultats préliminaires de l'étude 'La santé mentale en population générale: images et réalités'. Info Psychiatr 2000; 76: $293-8$.

18. Roelandt JL, Caria A, Anguis M, Benoist J, Bryden B, Defromont L. La santé mentale en population générale: images et réalités. Rapport final de la première phase d'enquête 1998-2000. EPSM Lille Métropole; 2001.

19. Goodfellow B, Calandreau F, Roelandt JL. Psychiatric epidemiology in New Caledonia. Int J Ment Health 2010; 39: 68-81.

20. Bellamy V, Roelandt JL, Caria A. Premiers résultats de l'enquête Santé mentale en population générale: images et réalités. Info Psychiatr 2005; 81: 295-304.

21. Ballon N, Ursulet G, Merle S, Eynaud M, Charles-Nicolas A, Michalon M. Excess of psychoses among the French West Indian population. Can J Psychiatry 2004; 49: 335-8.

22. Omnes C, Vaiva G, Philippe A, Rouillon F, Roelandt JL. Risque suicidaire dans l'enquête Santé Mentale en Population Générale: premiers résultats. Info Psychiatr 2005; 81: 308-12. 